\title{
Revision of the Oriental leafhopper genus Toba with description of a related new genus (Hemiptera: Cicadellidae: Stegelytrinae)
}

\author{
Cong WEI ${ }^{1 *}$, Mick D. WEBB ${ }^{2}$ and YALIN $\mathrm{ZHANG}^{1 * *}$ \\ ${ }^{1}$ Key Laboratory of Plant Protection Resources and Pest Management, Ministry of Education, Entomological Museum, Northwest A \\ \& F University, Yangling, Shaanxi, 712100, China; e-mails: weicong215@163.net; yalinzh@nwsuaf.edu.cn \\ ${ }^{2}$ Department of Entomology, The Natural History Museum, Cromwell Road, South Kensington, SW7 5BD, London, UK; \\ e-mail: m.webb@nhm.ac.uk
}

Key words. Hemiptera, Cicadomorpha, Cicadellidae, Stegelytrinae, revision, new status, new genus, new species

\begin{abstract}
The Oriental leafhopper genus Toba Schmidt is reviewed and placed in the subfamily Stegelytrinae Baker. Its type species, T. fasciculata Schmidt, and a new species T. sandakanensis Wei \& Webb, are described with details of the male and female genitalia given for the first time. A related new genus and species, Paratoba longa Wei \& Webb, gen. n. and sp. n., are described. The subfamily status and the morphological similarities between these two genera and other taxa are discussed.
\end{abstract}

\section{INTRODUCTION}

The leafhopper genus Toba Schmidt 1911 was erected for its type species, Toba fasciculata Schmidt 1911, based on a strange looking female (Schmidt, 1911), and placed in the subfamily Jassinae. Subsequently, the genus was placed in Coelidiinae by Evans (1947) and Metcalf (1966), but excluded from this subfamily by Nielson (1975) and unassigned by Oman et al. (1990). In the present paper we redescribe and illustrate this poorly known genus with details of both the male and female genitalia given for the first time. In addition, descriptions are given of the two included species (one new) and a new related genus and its type species. All taxa are very rare in collections.

Based on a re-assessment of their overall features, we conclude that Toba and the new genus are members of Stegelytrinae Baker 1915. This leafhopper subfamily from the Palaearctic and Oriental regions is remarkably diverse with the Oriental genera being either only recently placed in the subfamily (being unassigned by Oman et al., 1990), or more recently described or revised (see Webb, 1999; Wei \& Zhang, 2003; Zhang \& Wei, 2002; Zhang et al., 2002, 2004, 2006a, b).

Materials examined are deposited in various institutions abbreviated in the text as follows: BMNH - The Natural History Museum, London, UK; BPBM - Bernice P. Bishop Museum, Hawaii, USA; MNHN - Muséum National d'Histoire Naturelle, Paris, France; NMNH - The National Museum of Natural History, USA; MIZW - Museum and Institute of Zoology, Polish Academy of Sciences, Wilcza, Warszawa, Poland.

\section{Genus Toba Schmidt, 1911}

Toba Schmidt 1911: 301. Type species: Toba fasciculata Schmidt.
Description. Large to very large leafhoppers. Body with tufts of setae (Figs 23, 24, 32, 50).

Head small, distinctly narrower than pronotum (Figs 23, 24, 32, 50). Vertex longer than width between eyes; area between lateral frontal sutures slightly swollen, sloping to front; anterior margin rounded; posterior margin slightly concave; coronal suture distinct basally. Ocelli on vertex, near anterior margin, situated approximately half length to two thirds their own diameters from corresponding eye. Face much longer than width; lateral frontal suture extending well beyond lateral margin of corresponding ocellus; transclypeal suture somewhat indistinct (Fig. 25). Anteclypeus broadening apically, apical margin slightly convex; gena nearly flat, slightly longitudinally concave beneath eye; lora broad (Figs 25, 51). Rostrum long, slightly shorter than clypellus; labrum about three fifths length of labium. Antenna slightly longer than body length, arising adjacent midpoint of inner margin of eye; antennal ledge distinct; antennal pit deep. Anterior tentorial arm long, very slightly expanded apically (Fig. 5). Proepisternum prominent (Fig. 51). Pronotum about $2 \times$ broader than median length; posterior margin distinctly concave; lateral margin long, carinate, curved to eye anteriorly (Figs 50, 51). Scutellum slightly longer than pronotum; basal width similar to width of head; transverse depression somewhat indistinct; posterior half weakly elevated and inclined from transverse suture; posterolateral ledge distinct or indistinct; median ridge distinct or absent (Figs 23, 24, 50, 51). Forewing with five apical cells; middle and outer subapical cells closed, inner subapical cell open; claval veins fused medially; cross vein present between inner claval vein and claval suture; appendix broad with margin rounded, extended to fourth apical cell; claval margin strongly ele-

\footnotetext{
* Visiting scholar of The Natural History Museum, London, UK, from March of 2006 to March of 2007.

** Corresponding author.
} 

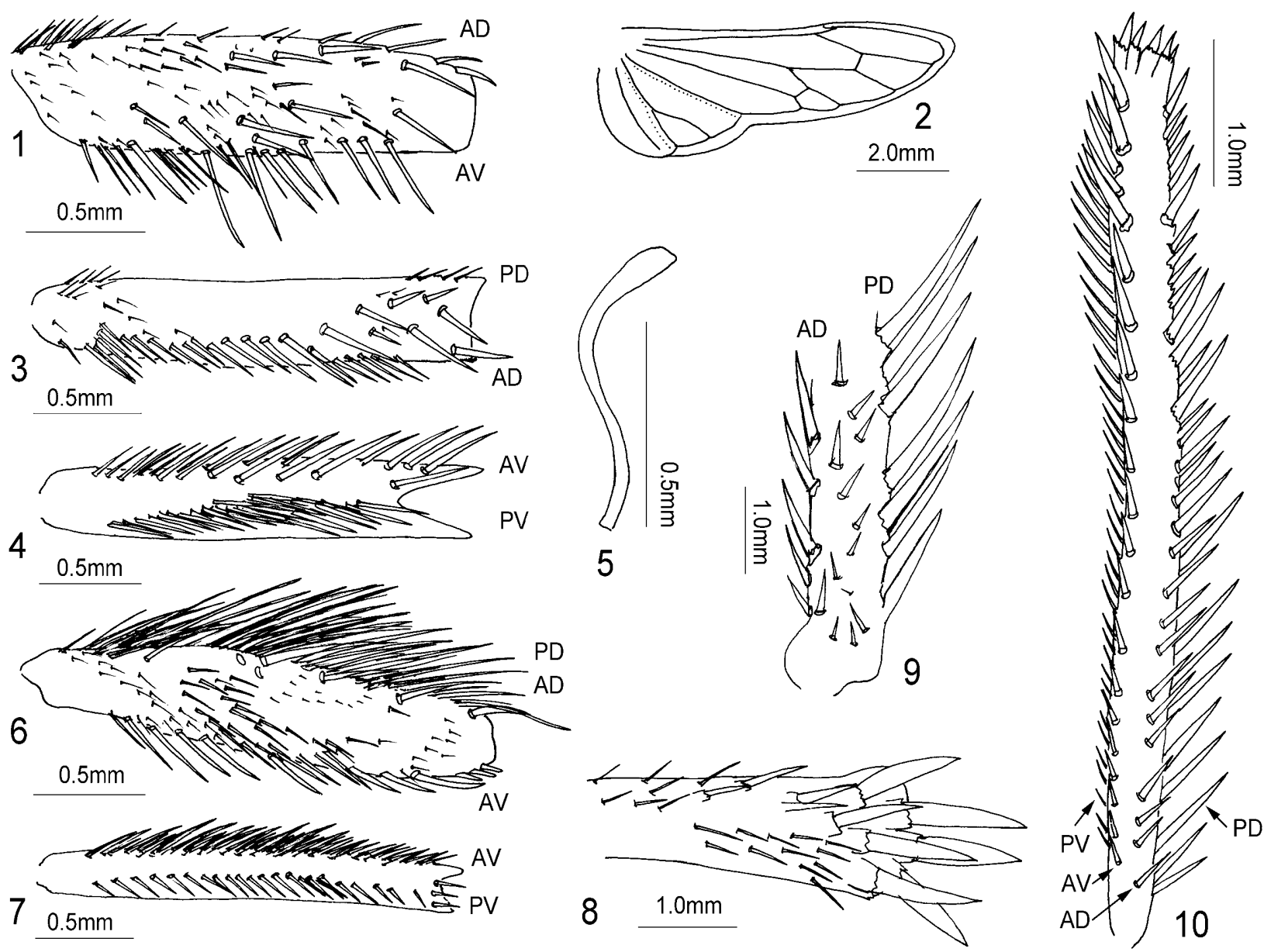

Figs 1-10: Toba fasciculata. AD, AV, PD, PV represents anterodorsal, anteroventral, posterodarsal, posteroventral setal row respectively. 1 - fore femur, anterior surface; 2 - hind wing; 3 - fore femur, dorsal surface; 4 - fore femur, ventral surface; 5 - anterior tentorial arm; 6 - fore tibia, anterior surface; 7 - fore tibia, ventral surface; 8 - apex of hind femur, dorsal surface; 9 - base of hind tibia, dorsal surface; 10 - hind tibia, anterior surface.

vated, crimped at apex (Figs 23, 24, 32). Hind wing venation complete; m-cu crossvein subapical (Fig. 2). Legs densely setose. Fore femur with fine macrosetae, setae short to long: anterior surface with intercalary (IC) setae very long and anteromedial (AM) setae irregular (Fig. 1); dorsal surface with anterodorsal (AD) setae and posterodorsal (PD) setae unarranged apically, several posterodorsal short setae unarranged basally (Fig. 3); ventral surface with AV setae long, PV setae relatively thicker and dense (Fig. 4). Fore tibia with anterodorsal and posterodorsal setae very fine and long, very dense and unarranged (Fig. 6); anteroventral (AV) setae very dense, posteroventral (PV) setae relatively shorter and sparse (Fig. 7). Hind femur slightly broadened distally, with several distal setae elevated on strong bases and several short setae subbasally (Figs 8, 52, 53). Hind tibia flattened and very slightly bowed; several accessory setae present between anterodorsal and posterodorsal rows; posterodorsal row setae very long (Figs 9, 10).

Male pygofer side broad, with dense macrosetae medially and short setae near distal margin; basal dorsal margin distinctly higher than Xth segment (Figs 11, 27). Phragma with weakly developed sclerotised areas comprising a star-shaped medial area (dorsal connective) adjacent dorsal apodeme of aedeagus (Figs 15, 17, 29, $31)$. Xth segment large; XIth segment distinctly sclerotised laterally (Figs 12,14) (see remarks). Valve large, posterior margin slightly or well angularly produced apically in ventral view (Figs 16, 30). Subgenital plate membranously attached to pygofer subbasally; moderately long, broadly rounded apically with several long setae near outer margin; a sclerotised band medially articulated with style (Figs 16, 30). Connective somewhat Y-shaped; stem broad, well sclerotised medially, membranous laterally; arms strong (Figs 15, 16, 30). Style with inner basal arm very short, outer basal arm elongate; preapical lobe very weakly developed with several setae adjacent apical process; apical process strongly curved laterally, tapered to apex, crenulate ventrally (Figs 15, 16, 30). Aedeagus with an elongate processes arising from each side of base; basal apodeme short; shaft elongate, curved dorsally and evenly tapered to acute apex, cylindrical, gonopore apical, surface position obscure (Figs 13, 15, 17, 28, 29, 31).

Female pygofer with ventroposterior margin incurved (Fig. 19). First valvulae tapered apically, sculpture comprising striations, aligned longitudinally basally and oblique distally (Figs 19, 20). Second valvulae with 


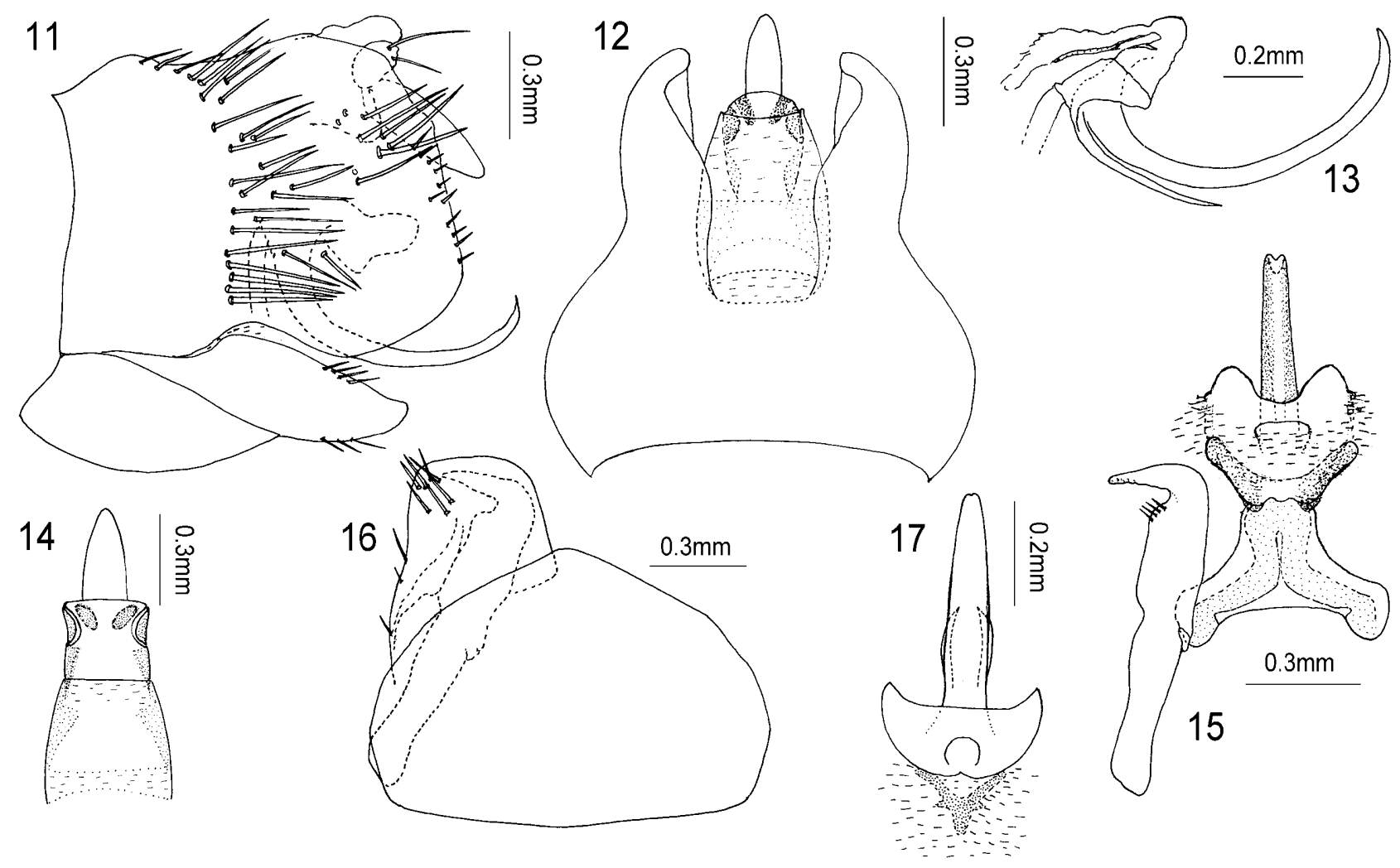

Figs 11-17: Toba fasciculata. 11 - male genital capsule and anal tube, lateral view; 12 - male genital capsule and anal tube, dorsal view; 13 - apex of connective and aedeagus, lateral view; 14 - anal tube, dorsal view with XIth segment pulled out; 15 - style, connective, dorsal connective and aedeagus; dorsal view with connective levelled; 16 - valve, subgenital plate and style, ventral view; 17 - dorsal connective and aedeagus; dorsal view.

blade-like area extending over distal half, with teeth robust and truncate, dorsal sclerotised and hyaline areas present (Fig. 21). Third valvulae with ventral margin slightly incurved medially, expanded distal region extending over distal half (Fig. 22).

Distribution. Malay Peninsular, Sumatra, Sabah, Singapore.

Remarks. This genus is characterised by its very long face, the dense tufts of setae on body and the shape of aedeagus and connective. The shape of the male XIth segment is difficult to interpret as for most part of its dorsal area is membranous. It appears that it extends broadly beyond the apical sclerites forming a truncate margin in dorsal view (Fig. 14).

\section{Key to species of Toba}

- Male pygofer without posterodorsal process (Fig. 11); aedeagus with basal lateral process two-fifths length of shaft, slender and close to shaft in lateral view (Fig. 13), narrow basally in dorsal view (Fig. 17). fasciculata Schmidt

- Male pygofer with acute posterodorsal process (Fig. 27); aedeagus with basal lateral process about four-fifths length of shaft, robust and well separated from shaft in lateral view (Fig. 31), broad basally in dorsal view (Fig. 28)......... ................ sandakanensis Wei \& Webb, sp. n.

\section{Toba fasciculata Schmidt, 1911}

(Figs 1-22)

Toba fasciculata Schmidt, 1911: 303.
Description. Body length (incl. forewings): $\widehat{\star} 8.8 \mathrm{~mm}$, 우 $8.6-9.6 \mathrm{~mm}$.

Body blackish brown with face and lateral area of prothorax yellow; forewing with basal half dark brown and apical half hyaline, a blackish patch apically. Head, thorax and forewing with dense whitish to yellow setae.

Scutellum slightly carinate apically.

Male pygofer moderately long, somewhat truncate posteriorly in lateral view (Fig. 11). Male valve subtriangular (Fig. 16). Connective with basal membranous area between arms very short; stem membranous laterally (Fig. 15). Aedeagus with basal lateral process approximately two-fifths length of shaft, delicate and aligned close to shaft in lateral view (Fig. 13), narrow basally in dorsal view (Fig. 17).

Female $7^{\text {th }}$ sternite much longer than $6^{\text {th }}$ sternite, with posterior margin roundly convex laterally, strongly concave medially; with a lobe-like process developed anteriorly on inner surface (Fig. 18).

Biology. Unknown.

Material examined. Indonesia, Sumatra: Holotype $q$ (MIZW). Singapore: 1 đ (NMNH), coll. Baker (cleared). Malaysia: Malay Peninsula: $1 \delta^{\star}, 1$ ㅇ (MNHN), Perak, coll. Noualhier, 1898; Sabah: 1 ㅇ (NMNH), Sandakan, Baker; 1 ㅇ (BPBM), Tawau, Quoin Hill, 26.-29.vii.1962, Y. Hirashima.

Toba sandakanensis Wei \& Webb, sp. n.

(Figs 23-31) 

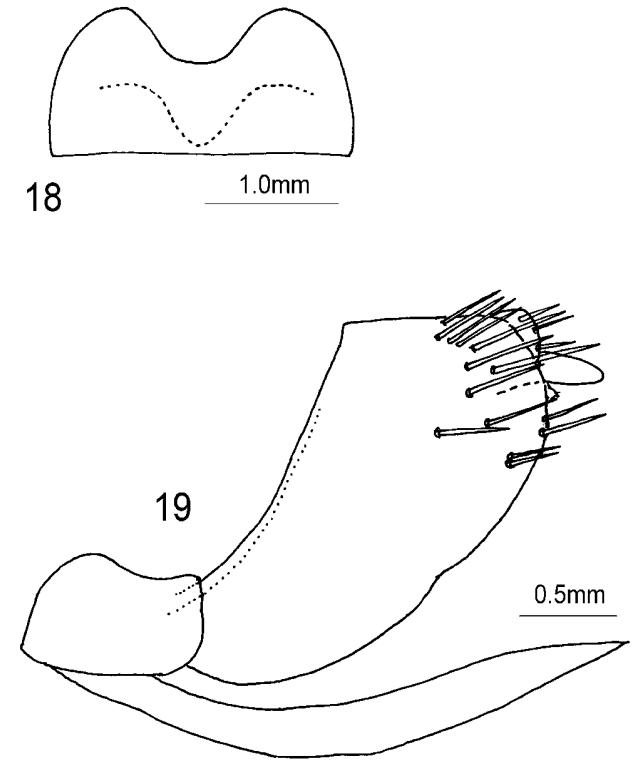

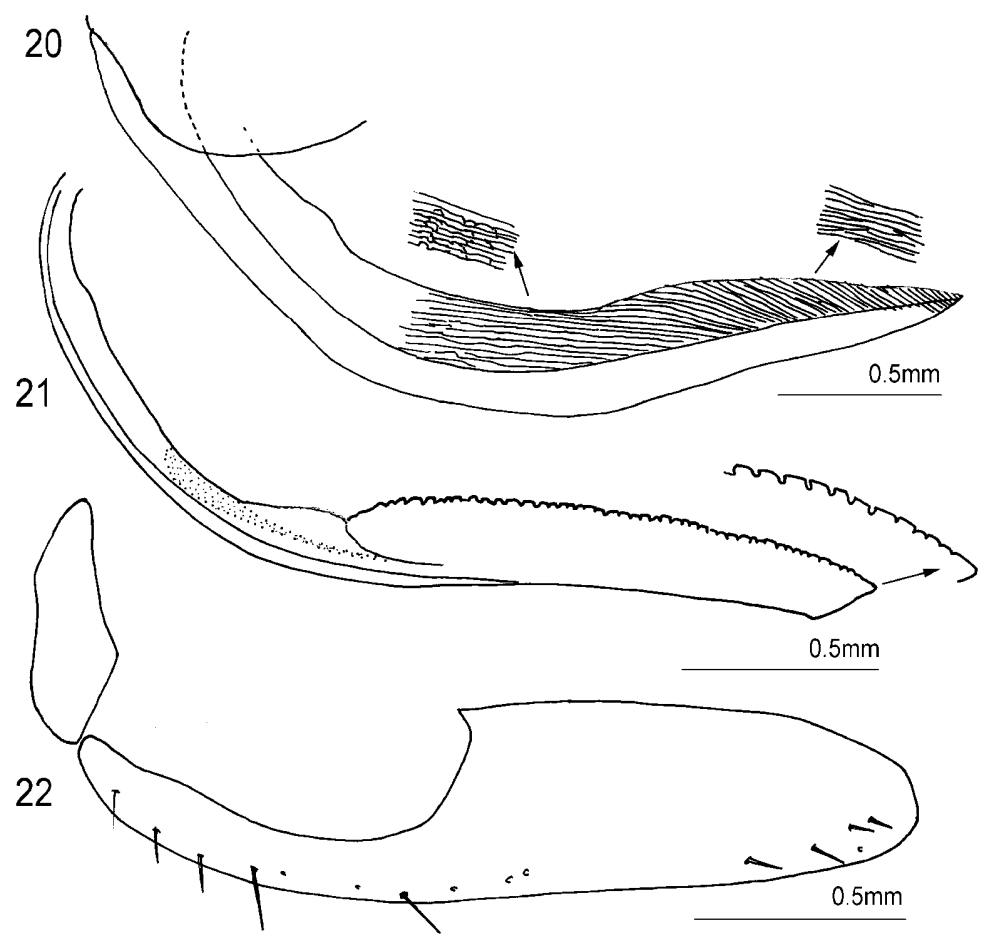

Figs 18-22: Toba fasciculata. 18 - female pregenital sternite, ventral view; 19 - female pygofer, first valvifer and first valvula, lateral view; 20 - first valvula and detail sculpture of first valvula; 21 - second valvula and detail of apex of second valvula; 22 second valvifer and third valvula.

Diagnosis. Differs from the preceding species by its setose abdomen, the angular process at the posterodorsal margin of male pygofer, the sub-quadrate valve and the longer basal lateral process of the aedeagus.

Description. Body length (incl. forewings): $\delta 8.7 \mathrm{~mm}$, o $8.8 \mathrm{~mm}$. Generally dark brown, with face and lateral area of prothorax yellow. Forewing with basal half brown, apical half hyaline, a slight brown patch apically (Figs 23, 24). Head, thorax and forewing with somewhat dense whitish to yellow setae; abdomen with black long setae laterally (Figs 23, 24).

Scutellum somewhat strongly carinate apically (Figs $23,24)$.

Male genitalia with valve subquadrate (Fig. 30). Connective with basal weakly sclerotised area between arms long (Fig. 30). Aedeagus with basal lateral process about four-fifths length of shaft, robust and broadly curved away from shaft in lateral view (Fig. 31), broad basally in dorsal view (Fig. 28).

Female genitalia with the $7^{\text {th }}$ sternite as in Toba fasciculata.

Biology. Unknown.

Material examined. Holotype: $\widehat{\delta}$ (BPBM), Malaysia, Sabah: Bettotan, Sandakan, 23.vii.1927. Paratype: 1 i (BPBM), same data as holotype except 10.viii.1927.

Etymology. The species name is derived from the type locality.

\section{Toba spp.}

Material examined. Malaysia, Malay Peninsula: 1 ㅇ (BMNH), Pahang, Fraser's Hill 4200 ft., 19.vii.1936, H.M.

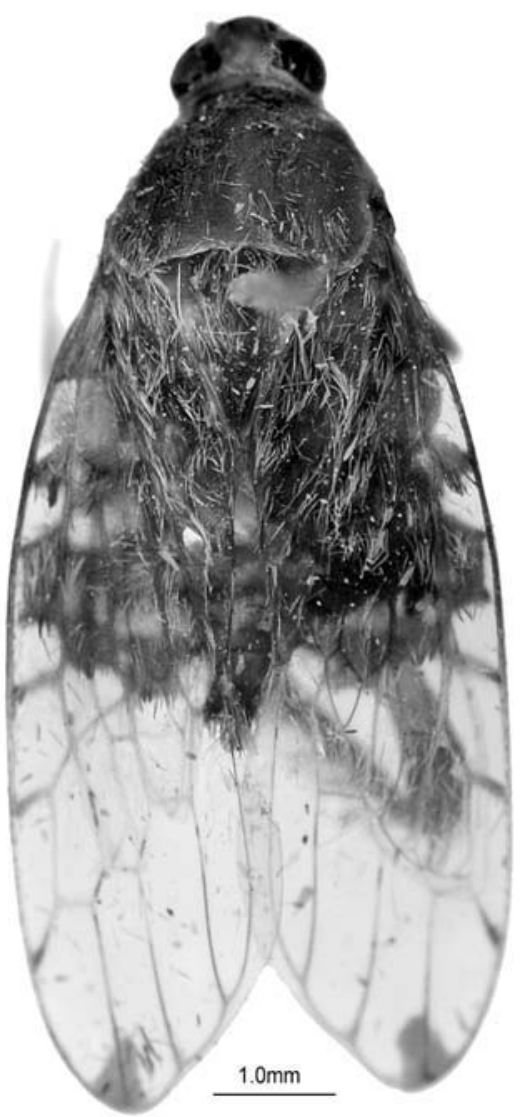

Fig. 23: Toba sandakanensis sp. n., male. Habitus adult. 


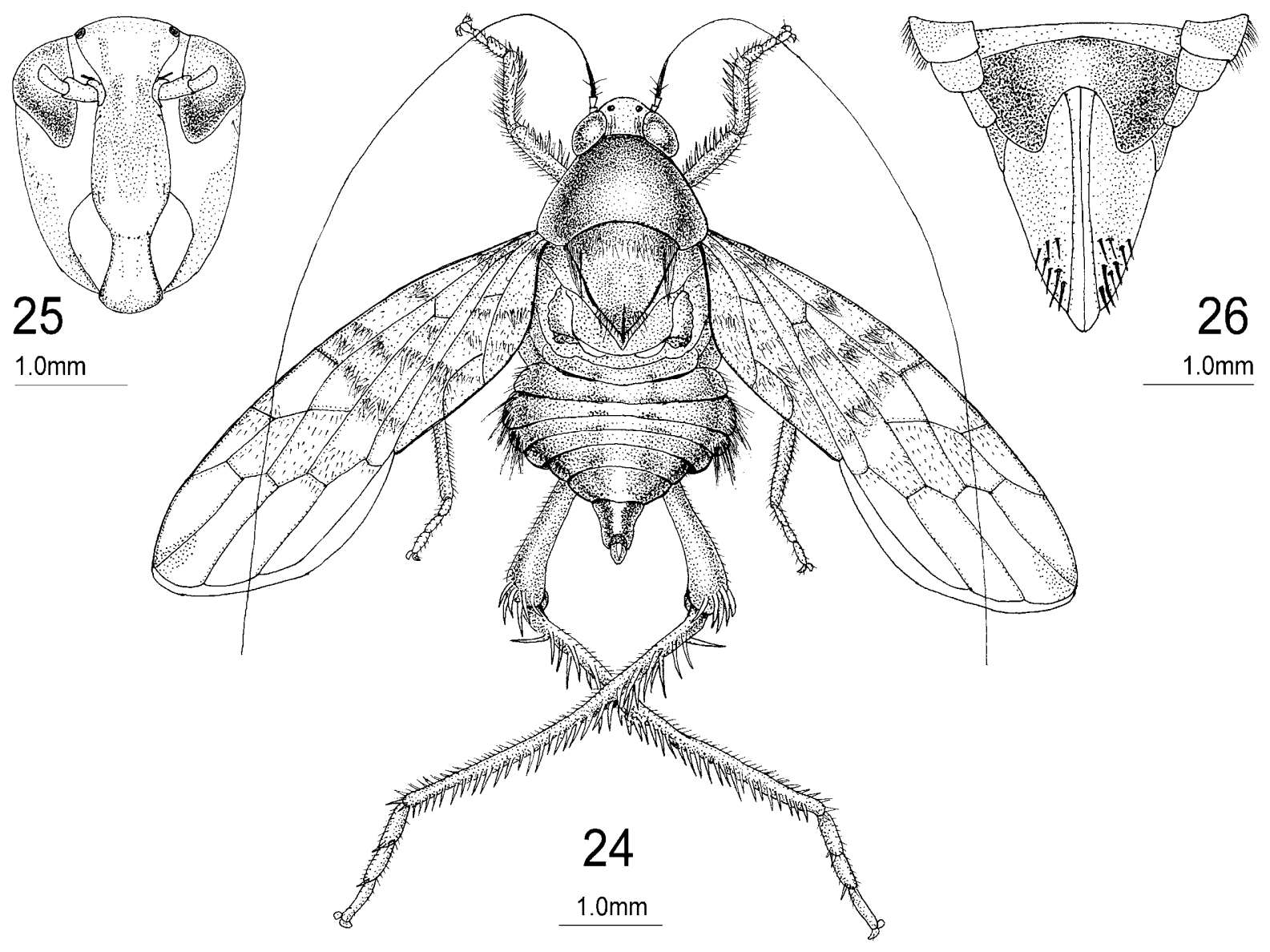

Figs 24-26: Toba sandakanensis sp. n., female. 24 - habitus adult; 25 - face; 26 - apex of abdomen, ventral view.

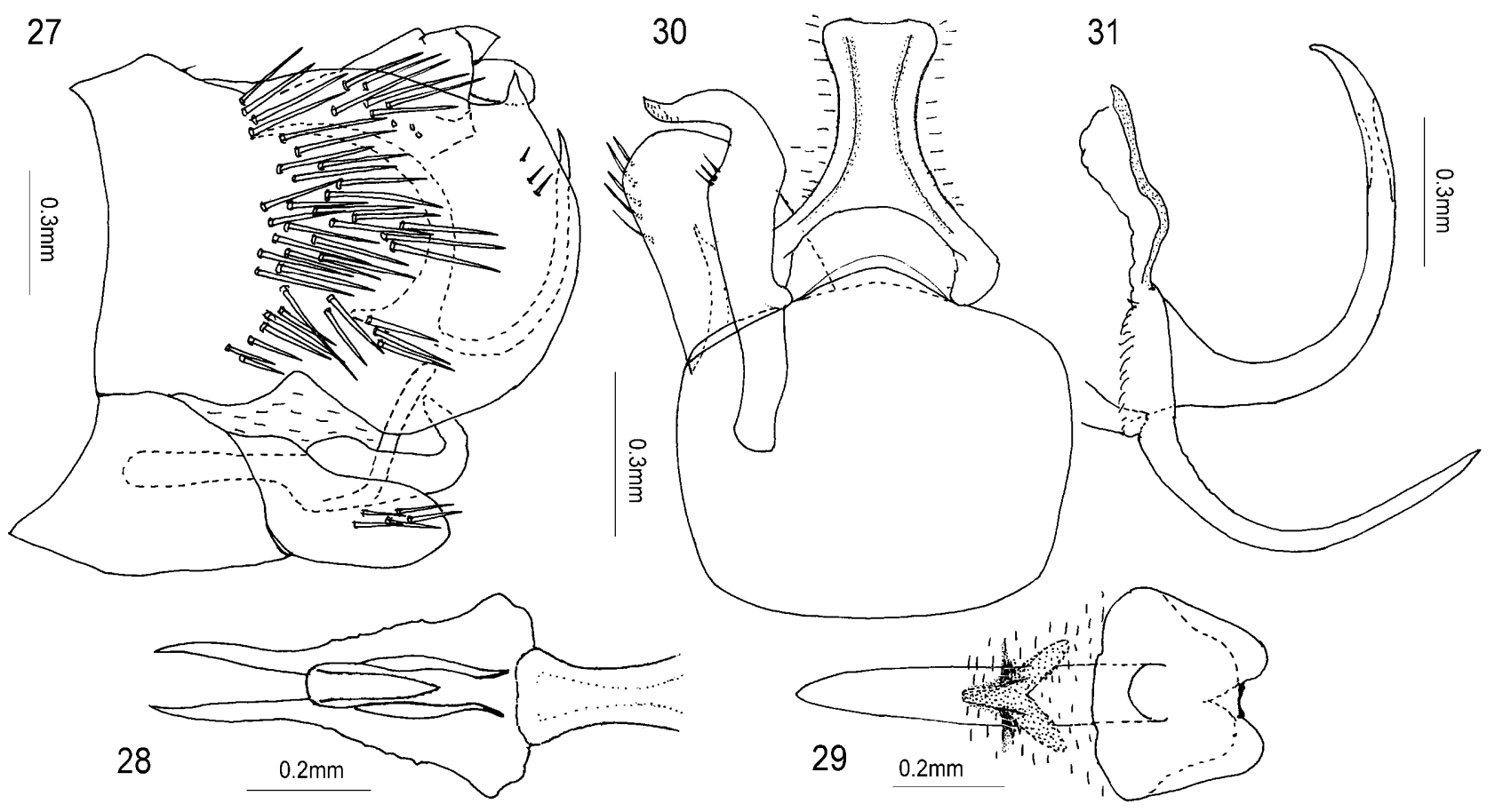

Figs 27-31: Toba sandakanensis sp. n., male. 27 - genital capsule and anal tube, lateral view; 28 - apex of connective and aedeagus, anterodorsal view; 29 - dorsal connective and aedeagus; anterodorsal view; 30 - valve, subgenital plate, style and connective, dorsal view; 31 - apex of connective, dorsal connective and aedeagus; lateral view. 


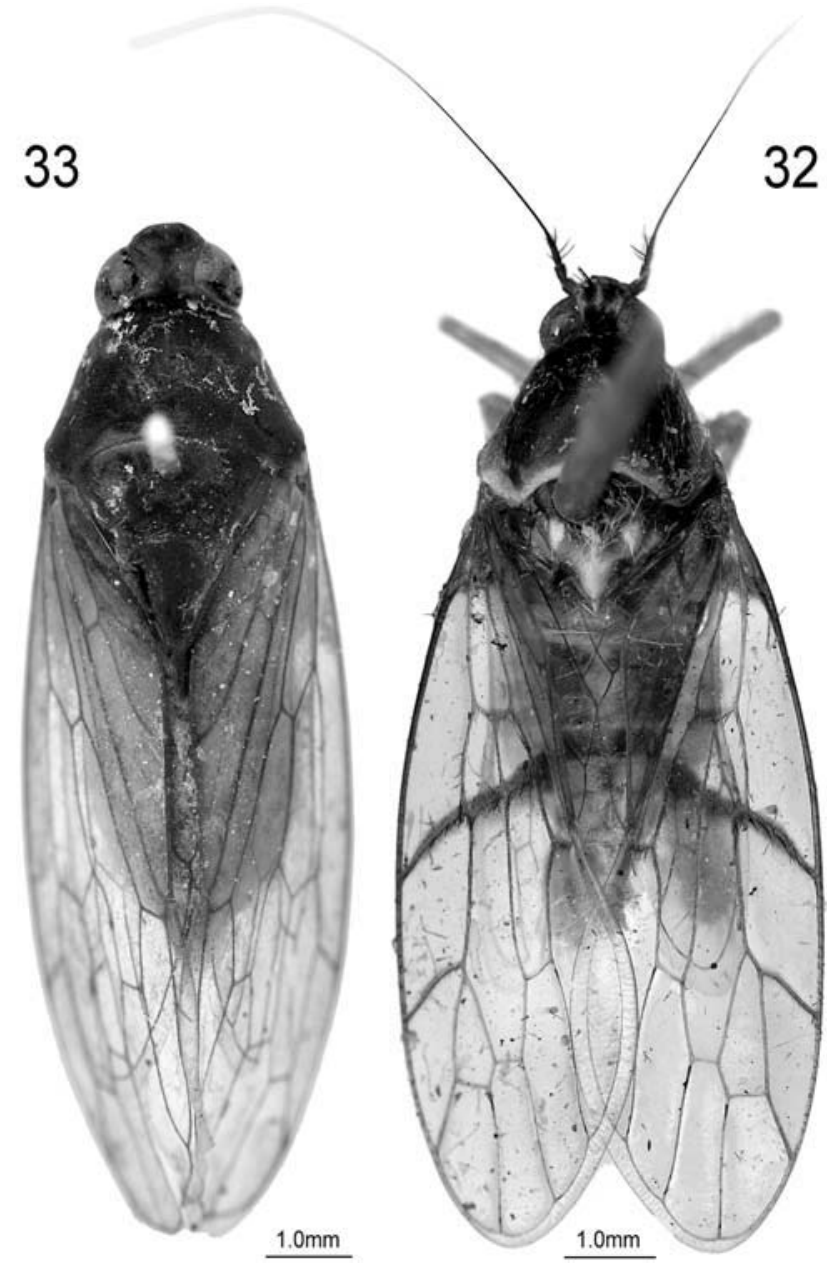

Figs 32-33: Adult habitus. 32 - Toba sp., Pahang; 33 - Paratoba longa sp. $\mathrm{n}$.
Pendlebury; Sarawak: 19 (BMNH) (damaged), Kuching, 26.iv.1899.

Remarks. These two female specimens are distinctly different from other Toba species. The female from Pahang (Fig. 32) has the following different characters: body longer $(10.2 \mathrm{~mm})$; carina on the apex of scutellum absent; forewing with a narrow reddish brown stripe near mid-length and without coloured patch apically; abdomen without hairs laterally. The female from Sarawak is darker, without setae on abdomen; the pregenital sternite moderately produced posteriorly and ovipositor is well extended beyond the pygofer. Whether these specimens represent new species needs to be investigated further when associated males are available.

\section{Genus Paratoba Wei \& Webb, gen. n.}

(Figs 39-49)

Type species: Paratoba longa Wei \& Webb, sp. n.

Diagnosis. This new genus is very similar to Toba Schmidt but can be distinguished from it by its more elongate body and face, the absence of setae on the body and forewing, the leg setal formula, the shape of anteclypeus, the bifurcate short process between the first valvulae, and by the shape of the second valvulae.

Description. Very large $(>10 \mathrm{~mm})$. Body smooth, without tufts of setae.

Head small, distinctly narrower than pronotum, slightly narrower than scutellum. Vertex longer than width between eyes; area between lateral frontal sutures distinctly swollen, sloping to front; anterior margin rounded; posterior margin slightly concave; coronal suture distinct basally. Ocellus on vertex, near anterior margin, situated approximately two thirds its own diameter from corresponding eye. Face much longer than width; lateral

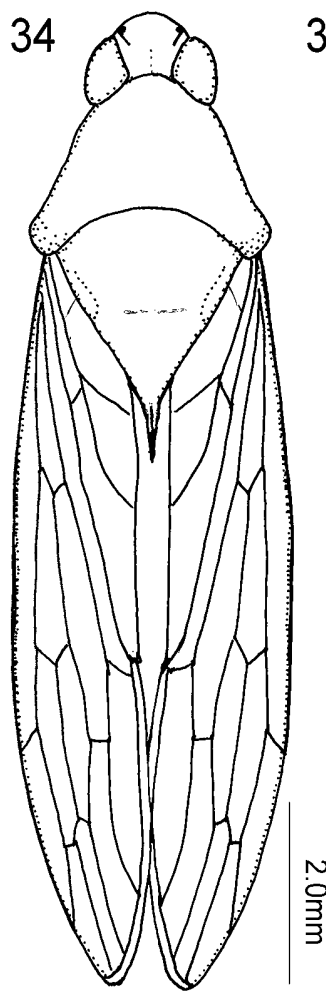

35
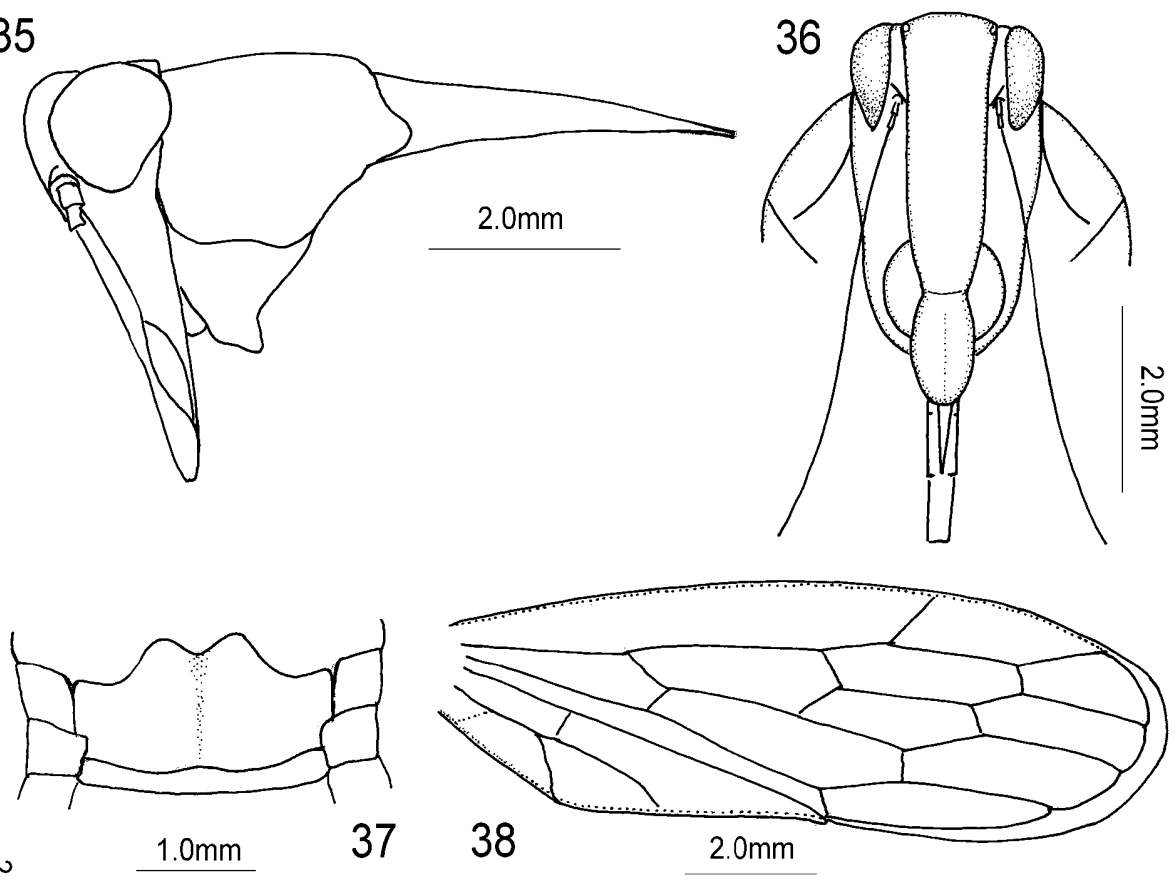

Fig. 34-38: Paratoba longa sp. n. 34 - habitus adult; 35 - head and thorax, lateral view; 36 - face and prothorax; 37 - subapical part of abdomen, ventral view; 38 - forewing. 

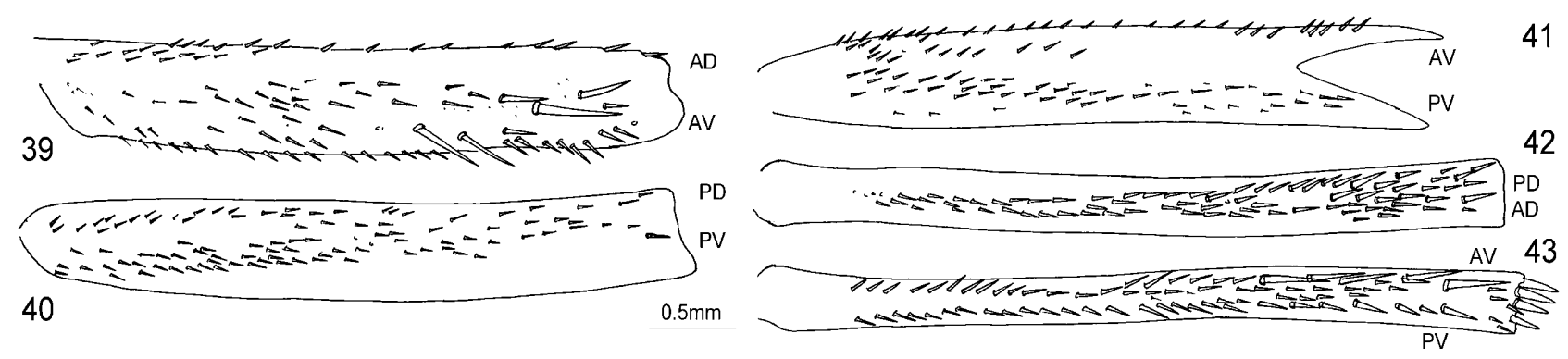

Figs 39-43: Paratoba longa sp. n., AD, AV, PD, PV represents anterodorsal, anteroventral, posterodarsal, posteroventral setal row respectively. 39 - fore femur, anterior surface; 40 - fore femur, dorsal surface; 41 - fore femur, ventral surface; 42 - fore tibia, dorsal surface; 43 - fore tibia, ventral surface.

frontal suture extending well beyond lateral margin of corresponding ocellus; transclypeal suture somewhat indistinct (Figs 35, 36). Anteclypeus broadened medially, elevated and forming a slight longitudinal medial ridge, apical margin convex (Fig. 36). Gena slightly longitudinally concave beneath eyes; lora broad. Rostrum long, slightly longer than clypellus; labrum about half length of labium (Fig. 36). Antenna about as long as body, arising slightly below midpoint of inner margin of eye; antennal ledge distinct; antennal pit deep. Proepisternum prominent (Fig. 35). Pronotum about $2 \times$ broader than median length; posterior margin strongly concave; lateral margin long, carinate, curved to eye anteriorly; posterolateral area slightly convex (Figs 33-35). Scutellum much longer than pronotum; transversal depression somewhat indistinct; posterior half weakly elevated and inclined from transverse suture; posterolateral ledge distinct; median ridge short (Figs 33-35). Forewing with five apical cells; middle and outer subapical cells closed, inner subapical cell open; claval veins fused medially; cross vein present between inner claval vein and claval suture; appendix broad with margin rounded, extended to fourth apical cell; claval margin strongly elevated and crimped at apex (Fig. 38). Hind wing venation complete. Legs with setae very short. Fore femur with anterior surface with inter- calary (IC) setae very short and anteromedial (AM) setae short to long, unarranged (Fig. 39); dorsal surface with anterodorsal setae and posterodorsal setae very short, unarranged apically (Fig. 40); ventral surface with anteroventral and posteroventral setae very short, unarranged (Fig. 41). Fore tibia with very short setae extending from base to apex on both dorsal and ventral surface (Figs 42, 43).

Male unknown.

Female pygofer with ventroposterior margin slightly incurved (Fig. 45). First valvulae connected by a bifurcate process (Figs 44, 45); ventral margin sinuate medially, sculpture comprising short oblique striations (Figs 46, 47). Second valvulae with blade-like area extending to base, with dorsal margin sinuate (Fig. 49). Third valvulae with ventral margin smooth, expanded distal region extending over nearly distal half (Fig. 48).

Distribution. Malay Peninsula.

Etymology. The generic name is derived from its similarity to Toba.

Remarks. The above genus is described despite the lack of a male specimen as it has characters of interest, in particular probably the longest area of the face below the eyes of any cicadellid.

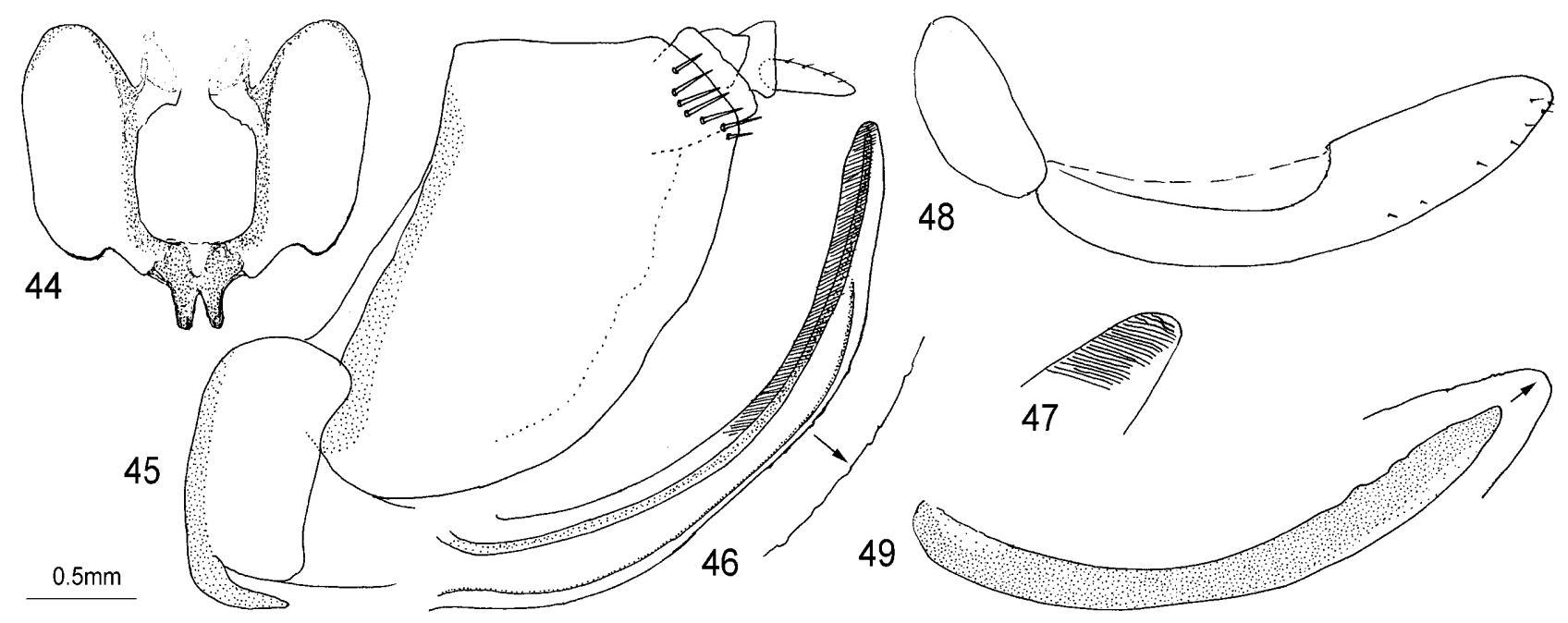

Figs 44-49: Paratoba longa sp. n. 44 - first valvifer, anterior view; 45 - female pygofer, first valvifer and base of first valvula, lateral view; 46 - first valvula and detail of ventral margin of first valvula; 47 - detail of apex of first valvula; 48 - second valvifer and third valvula; 49 - second valvula and detail of apex. 

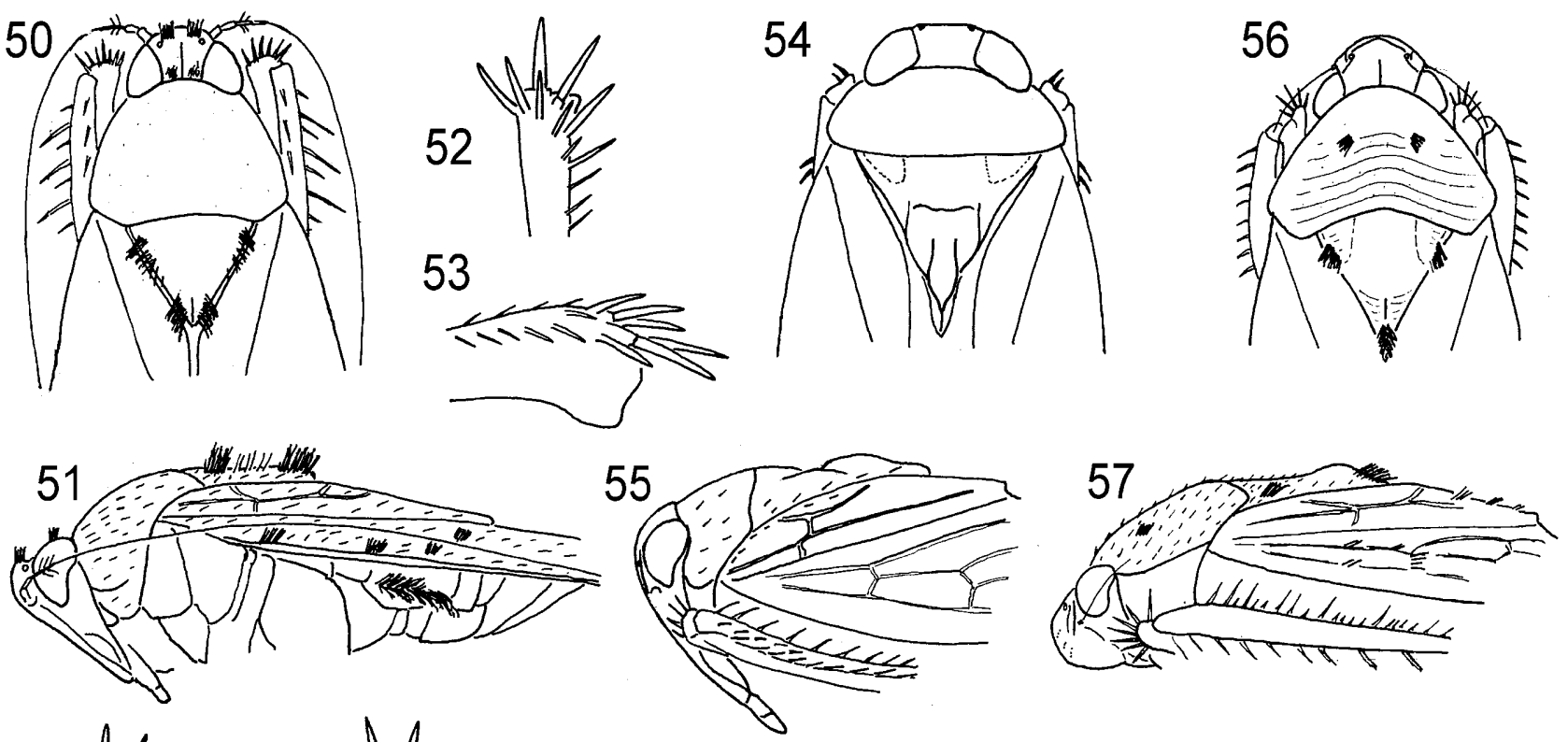

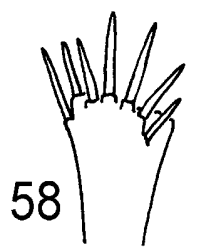

59

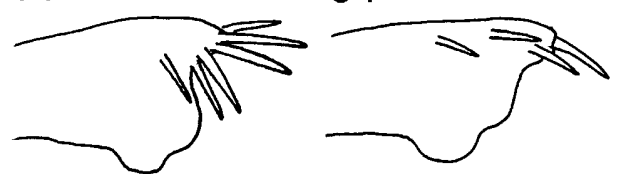

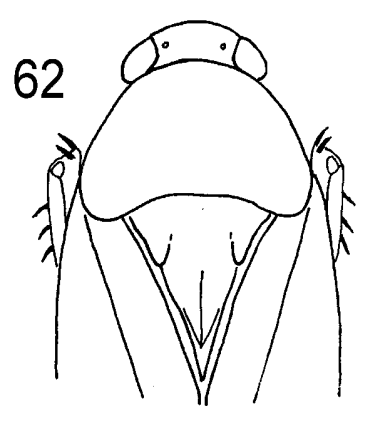

63

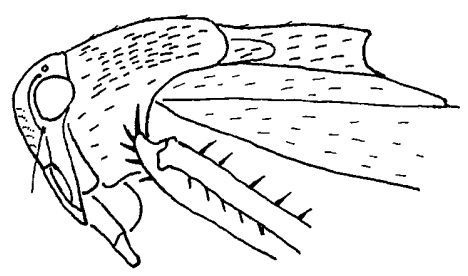

Figs 50-63: Representatives of various cicadellid subfamilies showing similar morphological characteristics (see Discussion for details): 50-55 (Stegelytrinae), 56-59 (Penthimiinae), 60-63 (Hylicinae). 50-53- Toba sandakanensis sp. n., 50, 51 - partial habitus adult, dorsal and lateral view; 52, 53 - apex of hind femur, dorsal and ventral surface. 54-55 - Placidellus sp. (BMNH), 54, 55 - partial habitus adult, dorsal and lateral view. 56-59 - Penthimidia eximia Haglund (BMNH), 56, 57 - partial habitus adult, dorsal and lateral view; 58, 59 - apex of hind femur, dorsal and ventral surface. 60-63 - Balala sp. (BMNH), 60, 61 - apex of hind femur, dorsal and ventral surface; 62, 63 - partial habitus adult, dorsal and lateral view.

\section{Paratoba longa Wei \& Webb sp. n.}

(Figs 33-49)

Description. Body length (incl. forewings): $\$ 10.4$ $\mathrm{mm}$. Generally dark brown, with dorsal surface of thorax blackish; forewing pale, nearly hyaline (Fig. 33). Female $7^{\text {th }}$ sternite much longer than $6^{\text {th }}$ sternite, with posterior margin produced lobe-like each side of mid-line (Fig. 37). Other characters are as described for the genus.

Material. Holotype: + (BMNH), Malaysia, Malay Peninsula: Perak, Gunong Kledang, xi.1916.

Etymology. The species name is derived from its very long face.

Remarks. The hind legs of the only known specimen of this species are missing.

\section{DISCUSSION}

Toba Schmidt is poorly known due to its rarity in collections, and was previously associated with Coelidiinae (which it superficially resembles), but since its exclusion from that subfamily by Nielson (1975) it has been unas- signed (Oman et al., 1990), although tentatively assigned to Stegelytrinae by Webb (1999). In fact, it and Paratoba gen. n. share characters with genera of Stegelytrinae (mainly Oriental genera, see below), Hylicinae (Balala) (Figs 60-63) and Penthimiinae (Penthimidia) (Figs 56-59), e.g., body with conspicuous setae; head small; scutellum elevated and carinate posteriorly; apex of clavus crimped; and the apical hind femoral setae well elevated on strong bases. Additional similarities with Penthimidia are the presence of setal tufts on the head, thorax and abdomen, the fused claval veins and the long hind femur with relatively numerous and apically situated distal setae of the hind femur (Figs 56-59). However, we conclude that Toba and Paratoba gen.n. are related to the genera of Oriental Stegelytrinae based on the following characters: fly-like appearance (Figs 23, 24, 32, 33) (shared with Doda Distant); eyes strongly encroaching onto pronotum laterally and relatively more dorsad in relation to pronotal carina in lateral view (except Temburocera Webb); antenna long; lateral frontal suture extending well beyond corresponding ocellus (Figs 24, 
34); forewing with middle and outer subapical cells closed and inner subapical cell open (Figs 23, 24, 32, 38); accessory setae present between anterodorsal and anteroventral rows of hind tibia (Fig. 9); median carina on apex of scutellum (shared with Doda Distant, Kunasia Distant, Paraplacidellus Zhang, Wei \& Shen and Placidellus Evans) (Figs 50, 54); claval veins fused; tufts of setae on body (shared with some species of Placidus Distant) (Figs 24, 38); posterior margin of female pygofer incurved (Figs 19, 45); dorsal connective of male pygofer phragma present (Figs 15, 17, 29).

ACKNOWLEDGMENTS. We would like to express our sincere thanks to the BPBM, MNHN, NMNH and the MIZW for lending us the specimens on which this study is based. Thanks are also made to C. Dietrich (Illinois Natural History Survey, USA) for comments on the manuscript. This study is supported by the National Natural Science Foundation of China (grant no. 30670256), and Northwest A \& F University Grants for Outstanding Faculty Members and Excellent Competent Personnel Foundation. The senior author is supported by the State Scholarship Fund of China to pursue his research related to this paper at The Natural History Museum, London, UK, from March of 2006 to March of 2007.

\section{REFERENCES}

Evans J.W. 1947: A natural classification of leafhoppers (Jassoidea; Homoptera). Part 3: Jassidae. Trans. Entomol. Soc. London 98: 105-271.

Metcalf Z.P. 1966: General Catalogue of the Homoptera Fascicle VI. Cicadelloidea Part 16, Idioceridae. Agricultural Research Service, U.S. Department of Agriculture, Washington, D.C., 237 pp.
Nielson M.W. 1975: A revision of the Subfamily Coelidiinae (Homoptera: Cicadellidae), Tribes Tinobregmini, Sandersellini and Tharrini. Bull. Br. Mus. Nat. Hist. (Entomol. Suppl.) 24: 1-197.

OMan P.W., KNIGHT W.J. \& Nielson M.W. 1990: Leafhoppers (Cicadellidae): A Bibliography, Generic Checklist and Index to the World Literature 1956-1985. C.A.B. International Institute of Entomology, Wallingford, $368 \mathrm{pp}$.

Schmidt E. 1911: Beitrag zur Kenntnis der Homopteren. (Neue Gattungen und Arten). Stett. Entomol. Ztg. 72: 238-307.

WeBB M.D. 1999: Identity of Bythoscopus ignicans Walker, 1857 (Hemiptera: Auchenorrhyncha: Cicadomorpha: Cicadellidae: Stegelytrinae). Reichenbachia 33(14): 111-114.

Wei C. \& Zhang Y.L. 2003: A new species of the genus Placidus (Homoptera: Cicadellidae: Stegelytrinae) from Nepal. Entotaxonomia 25(4): 91-94.

Zhang Y.L. \& Wei C. 2002a: Study on the oriental leafhopper genus Kunasia Distant (Homoptera: Cicadellidae). Entotaxonomia 24(2): 83-88.

Zhang Y.L. \& Wei C. 2002b: A systematic study on the genus Placidus Distant (Homoptera: Cicadellidae). Entomol. Sinica 9: $63-72$.

Zhang Y.L., Wei C. \& Shen L. 2002: A new species of Placidellus Evans and a related new genus (Homoptera: Cicadellidae). Entotaxonomia 24(4): 239-244.

Zhang Y.L, WebB M.D. \& Wei C. 2004: The Oriental leafhopper genus Doda Distant (Auchenorrhycha: Cicadellidae). System. Biodiv. 1: 301-303.

Zhang Y.L, Wei C. \& WebB M.D. 2006a: Two new oriental stegelytrine leafhopper genera (Insecta: Hemiptera: Cicadellidae). Proc. Entomol. Soc. Wash. 108: 289-296.

Zhang Y.L, Wei C. \& WebB M.D. 2006b: A new stegelytrine leafhopper genus from China and Thailand (Hemiptera: Cicadellidae). Zootaxa 1333: 55-62.

Received September 11, 2006; revised and accepted November 2, 2006 